International Journal of Biological Sciences

ISSN 1449-2288 www.biolsci.org 2006 2(2):73-78

Research paper

C2006 Ivyspring International Publisher. All rights reserved

\title{
Immunohistochemical study of cytoskeletal and extracellular matrix components in the notochord and notochordal sheath of amphioxus
}

\author{
Ivana Bočina1 and Mirna Saraga-Babić ${ }^{2}$ \\ ${ }^{1}$ Department of Biology, Faculty of Natural Scieneces, University of Split, Teslina 12, 21000 Split, Croatia \\ ${ }^{2}$ Department of Anatomy, Histology and Embryology, Medical School, University of Split, PAK, Spinčićeva 1, Croatia
}

Corresponding address: Ivana Bočina. Department of Biology, Faculty of Natural Scieneces, University of Split, Teslina 12, 21000 Split, Croatia. Tel. 38521385 133. Fax: 38521385 431. E-mail: bocina@pmfst.hr

Received: 2006.02.08; Accepted: 2006.03.10; Published: 2006.04.10

A major cytoskeletal and extracellular matrix proteins of the amphioxus notochordal cells and sheath were detected by immunohistochemical techniques. The three-layered amphioxus notochordal sheath strongly expressed fish collagen type I in its outer and middle layers, while in the innermost layer expression did not occur. The amphioxus notochordal sheath was reactive to applied anti-human antibodies for intermediate filament proteins such as cytokeratins, desmin and vimentin, as well as to microtubule components (B-tubulin), particularly in the area close to the epipharyngeal groove. Alpha-smooth muscle actin was expressed in some notochordal cells and in the area of the notochordal attachment to the sheath. Thus muscular nature of notochordal cells was shown by immunohistochemistry in tissue section. Our results confirm that genes encoding intermediate filament proteins, microtubules and microfilaments are highly conserved during evolution. Collagen type I was proven to be the key extracellular matrix protein that forms the amphioxus notochordal sheath.

Key words: collagen, intermediate filaments, notochord, notochordal sheath

\section{Introduction}

Early investigations on the amphioxus notochord and its sheath described the notochordal sheath as an envelope completely surrounding the notochord and was considered to be a product of notochordal cells and Müller's tissue [1,2]. For a while, it was believed that it consists of elastic fibres and therefore was called the tunica elastica [3,4]. More recently, [5], the notochordal sheath was described as a very thick connective tissue sheath consisting of collagenous fibres of unusually large diameter and irregular outline, embedded in a slightly granular matrix. Most of the collagen fibres "followed a spiral course" [5], but they were also described as circular and longitudinal in orientation [6,7]. Our recent electron microscopic investigations showed the threelayered organization of the notochordal sheath in amphioxus [8]. Two layers (outer and middle layer) consisted of collagen fibres, while the innermost one was amorphous and resembled the basal lamina [8]. That ulrastructural study also indicated the presence of collagen type I in the notochordal sheath of amphioxus.

Although numerous investigations on the notochord of amphioxus were done during the last century, some biochemical features of amphioxus notochordal sheath still remained unclear. Recent investigations on the notochord cells of amphioxus disclosed actin as a major component of the cellular microfilaments: using the EST (expressed sequence tag) analysis, 12 different types of muscle genes were revealed in amphioxus notochord cells [10]. One of these genes encoded neither cytplasmic nor skeletal type of actin, and therefore was marked as the actin specific only for amphioxus notochord [11]. In situ hybridization showed a weak signal of this gene also in somites of the amphioxus neurula [11]. The other cytoskeletal elements, such as the intermediate filaments, were also detected in amphioxus notochord on molecular level [12]. Intermediate filaments (IF) form a major component of the eukaryotic cytoskeleton and have important roles in the function of specialized cell types [13]. The type I and type II IF gene classes both encode keratins expressed predominantly in epithelial cells. The type III IF, including vimentin, desmin, peripherin, and glial fibrillary acidic protein (GFAP), are predominantly expressed in mesenchymal cells. Similarly, type IV genes (neurofilaments) are expressed in neurones [13]. The proteins (nuclear lamins) of type V IF genes, function in the nucleus instead of the cytoplasm, forming a structural envelope beneath the nuclear membrane [13]. It was shown that amphioxus genome possesses genes which cover at least 12 different cytoplasmic proteins; three of them were defined as the homologues of the type I and II keratins [12,14]. Until now, neither of these cytoskeletal components was confirmed by immunohistochemistry in tissue sections of amphioxus notochord or in the notochordal sheath. In the present study, we investigated the presence of the cytoskeletal and 
extracellular matrix elements in tissue sections of amphioxus notochordal cells and notochordal sheath using immunohistochemical techniques.

\section{Material and Methods}

In the present study, ten adult individuals of amphioxus Branchiostoma lanceolatum L. were utilized. The specimens were collected in the Adriatic sea near Institute of Oceanography and Fisheries, Split, Croatia.

\section{Immunohistochemistry on paraffin sections}

The samples were cut into small pieces $(4-6 \mathrm{~mm}$ in length) and fixed in $4 \%$ paraformaldehyde in phosphate buffer. After dehydration in an ascending series of ethanol, and clearing in xylene, the tissues were embedded in paraffin, sectioned transversally at 4-6 $\mu \mathrm{m}$ and mounted on glass slides [15]. Paraffin sections were deparaffinised in xylene and rehydrated in ethanol and water. The sections were incubated for 30 minutes in $0.1 \% \mathrm{H}_{2} \mathrm{O}_{2}$ thus avoiding endogenous peroxidase activity. After washing with phosphate- buffered solution (PBS), the sections were incubated (if necessary) in sodium citrate or ethylenediaminetetraacetic acid (EDTA) buffer for 10 minutes at $95^{\circ} \mathrm{C}$ and cooled to room temperature. In order to avoid the background activity, sections were incubated in $10 \%$ normal goat serum for 20 minutes. The sections were incubated with several primary antibodies (Table 1) according to their own protocols. After applying the primary antibodies, the sections were incubated with mouse or rabbit secondary antibody for 30 minutes at room temperature. The sections were then washed in PBS, stained with diaminobenzidine tetrahydrochloride solution (DAB), and counter-stained with hematoxylin [16-27]. The negative controls were made for each primary antibody by labelling the tissues only with secondary antibody and staining with $\mathrm{DAB}$, thus abolishing the specific staining in amphioxus tissues.

The sections were analysed using an Olympus BX 40 light microscope.

Table 1. Characteristics of the applied primary antibodies (all monoclonal)

\begin{tabular}{|c|c|c|c|c|}
\hline Antibody & host & produced by & cat. number & dilution \\
\hline $\begin{array}{c}\text { Anti-Human Alpha-Smooth Muscle } \\
\text { Actin }\end{array}$ & mouse & DAKO, Glostrup, Denmark & M 0851 & $1: 150$ \\
\hline $\begin{array}{c}\beta \text {-tubulin (D-10) } \\
\text { Anti-Fish Collagen Type I }\end{array}$ & mouse & Santa Cruz Biotech.,Inc. & sc-5274 & $1: 100$ \\
\hline Anti-Human Cytokeratin MNF116 & mouse & BIODESIGN Int., USA & T8917R & $1: 50$ \\
\hline Anti-Human Cytokeratin 7 & mouse & DAKO, Glostrup, Denmark & M 7018 & $1: 50$ \\
\hline Anti-Human Cytokeratin 8 & mouse & DAKO, Glostrup, Denmark & M 631 & $1: 50$ \\
\hline Anti-Human Cytokeratin LP34, & mouse & DAKO, Glostrup, Denmark & N 1589 & $1: 50$ \\
\hline Anti-Human Cytokeratin 20 & mouse & DAKO, Glostrup, Denmark & M 7019 & $1: 30$ \\
\hline Anti-Human Desmin & mouse & DAKO, Glostrup, Denmark & M 0760 & $1: 150$ \\
\hline Anti-Vimentin/HRP & mouse & DAKO, Glostrup, Denmark & U 7034 & $1: 3000$ \\
\hline Anti-Human GFAP & mouse & DAKO, Glostrup, Denmark & M 0761 & $1: 60$ \\
\hline Anti-Human Nestin & mouse & R\&D Systems,Inc.,USA & MAB 1259 & $1: 30$ \\
\hline Anti-Human Neurofilament & mouse & DAKO, Glostrup, Denmark & M 0762 & $1: 150$ \\
\hline
\end{tabular}

\section{Results}

Antibodies to fish collagen type I, microfilaments, microtubules and intermediate filaments were used in order to elucidate the immunohistochemical characteristics of the notochordal sheath and notochordal cells in the amphioxus Branchiostoma lanceolatum (Table 2). Most of these antibodies labelled the amphioxus tissues, especially in the area of epipharyngeal groove. The negative controls made for each antibody completely abolished the immunoreaction in the tissue. The controls can also be provided by preabsorbtion of the primary antibody with the specific peptide [28].

\section{Anti-Fish Collagen Type I}

A strong positivity to anti-fish collagen type I was seen in the outer and middle layer of the notochordal sheath, while no positivity was seen in its innermost layer. Reactive parts of the sheath were stained intensively brown with diaminobenzidine tetrahydrochloride solution (DAB). Mild staining characterized the notochordal cells and their attachment to the sheath (Figure 1A).

Antibodies to microfilaments (Anti-Human aSmooth Muscle Actin) and microtubules ( $\beta$-tubulin D-10)

The amphioxus notochordal sheath showed no positivity to Anti-Human a-Smooth Muscle Actin. 
Very strong positivity was seen in the notochordal cells and in the area of their attachment to the sheath (Figure 1B).

The outer part of the notochordal sheath showed strong positivity to $\beta$-tubulin D-10 in the area of the epipharyngeal groove, where notochordal sheath touches the digestive tube as well (Figure 1C). A mild positivity was seen in the middle part of the sheath, near the neural tube (not shown).

Antibodies to cytokeratins (Cytokeratin MNF 116; Cytokeratin 7; Cytokeratin 8; Cytokeratin LP34, 34ßE12, 35ßH11; Cytokeratin 20)

Positivity to most of these cytokeratins was found in the outer or middle layers of the notochordal sheath in the area of the epipharyngeal groove as well as at the border between notochord and the neural tube (Table 2). Anti-Human Cytokeratin MNF 116 was present predominantly in the outer part of the sheath (Figure 1D), while Anti-Human Cytokeratin 20 was intensively expressed in both, outer and middle part of the sheath (data not shown). Anti-Human Cytokeratin 7 and Anti-Human Cytokeratin LP34, 34ßE12, 35ßH11 were expressed in the middle part of the sheath, while Anti-Human Cytokeratin 8 was expressed in the outer part of the sheath (data not shown). The positivity to cytokeratins on the border between the sheath and the neural tube was weaker then those near epipharyngeal groove. Only AntiHuman Cytokeratin LP34, 34ßE12, 35ßH11 was strongly expressed in the area where the notochordal sheath meets the neural tube (data not shown).

Figure 1. A) Anti-Fish Collagen Type I. (ns) notochordal sheath, (n) notochord. Note strong brown staining of outer part of the notochordal sheath, and absence of staining in its inner part. Mild brown staining characterizes notochordal cells and their attachment to the sheath (arrow). DAB 100x. B) Anti-Human $\alpha$-Smooth Muscle Actin. (ns) notochordal sheath, (nc) notochordal cell. Strong reactivity to actin observed in the notochordal cells and their attachment to the sheath (arrows). DAB 100x. C) B-tubulin D-10. (ns) notochordal sheath, (n) notochord, (epg) epipharyngeal groove. Notochordal sheath strongly reacts with ß-tubulin in its outer part, and mildly in its inner part. DAB 100x. D) Anti-Human Cytokeratin MNF 116. (ns) notochordal sheath, (n) notochord, (epg) epipharyngeal groove. Very strong expression of cytokeratin MNF 116 im the outer part of the notochordal sheath. DAB 100x. E) Anti-Human Vimentin. (n) notochord, (ns) notochordal sheath, (epg) epipharyngeal groove. Note strong brown staining of outer part of the notochordal sheath (arrows). DAB, 20x.
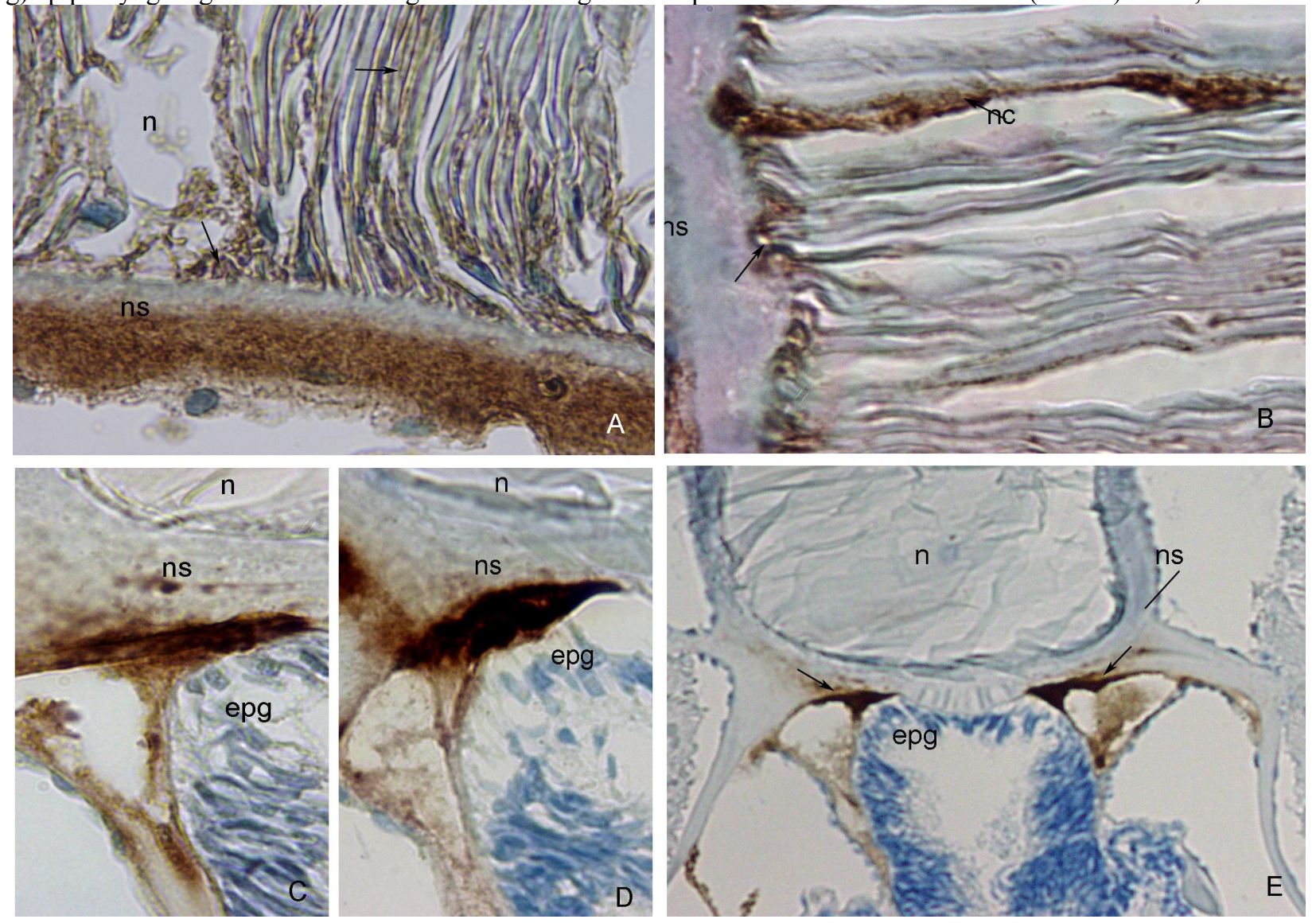

Table 2. Immunoreactivity of the notochord and its sheath to the applied primary antibodies.

\begin{tabular}{|c|c|c|c|}
\hline Antibody & Notochord & $\begin{array}{c}\text { Notochordal attachment to } \\
\text { the sheath }\end{array}$ & $\begin{array}{c}\text { outer /middle part of the } \\
\text { sheath }\end{array}$ \\
\hline Anti-Fish Collagen Type I & + & + & $+++/++$ \\
\hline $\begin{array}{c}\text { Anti-Human Alpha-Smooth } \\
\text { Muscle Actin }\end{array}$ & +++ & +++ & - \\
\hline
\end{tabular}




\begin{tabular}{|c|c|c|c|}
\hline Antibody & Notochord & $\begin{array}{c}\text { Notochordal attachment to } \\
\text { the sheath }\end{array}$ & $\begin{array}{c}\text { outer /middle part of the } \\
\text { sheath }\end{array}$ \\
\hline$\beta$-tubulin (D-10) & - & - & $+++/+$ \\
\hline $\begin{array}{c}\text { Anti-Human Cytokeratin } \\
\text { MNF116 }\end{array}$ & - & - & $+++/-$ \\
\hline Anti-Human Cytokeratin 20 & - & - & $+++/+++$ \\
\hline Anti-Human Cytokeratin 7 & - & - & $-/++$ \\
\hline $\begin{array}{c}\text { Anti-Human Cytokeratin } \\
\text { LP34, 34 \& E12, 35 \& H11 }\end{array}$ & - & - & $-/+++$ \\
\hline Anti-Human Cytokeratin 8 & - & - & $++/-$ \\
\hline Anti-Human Desmin & - & - & $+++/+$ \\
\hline Anti-Vimentin/HRP & - & - & $+++/+$ \\
\hline Anti-Human GFAP & - & - & - \\
\hline Anti-Human Neurofilament & - & - & $+++/+$ \\
\hline Anti-Human Nestin & - & - & - \\
\hline
\end{tabular}

$+++=$ very strong immunoreactivity, $++=$ strong immunoreactivity, $+=$ mild immunoreactivity, $-=$ no immunoreactivity

Antibodies to type III of intermediate filaments (Anti-Human Desmin, Anti-Human Vimentin, AntiHuman GFAP)

In the area of the epipharyngeal groove, the outer layer of the notochordal sheath was very reactive to desmin and vimentin antibodies (Figure 1E). Anti-Vimentin was also expressed in the notochordal sheath, on the border between notochord and neural tube. Anti-GFAP was not expressed in the notochordal sheath.

Antibody to type IV of intermediate filaments (Anti-Human Neurofilament) was also expressed in the outer layer of the sheath in the area of the epipharyngeal groove (data not shown).

Antibody to type VI of intermediate filaments (Anti-Human Nestin) was not expressed neither in notochord nor in the notochordal sheath.

\section{Discussion}

The notochordal sheath resembles the fibrilar net of tissue which encloses the notochord, thus controling its shape and stiffness [29]. It was first described as an elastic sheath called tunica elastica $[3,4]$. Later on, it was shown that it does not contain elastic fibres, both ultrastructurally and histochemically [8]. The notochordal sheath was also described as a connective tissue structure containing collagen fibres and the layer resembling basal lamina [5]. Three-layered structure of the amphioxus notochordal sheath was only recently described ultrastructurally: the outer and middle layer were made of collagen fibres, while the innermost layer resembled the basal lamina [8]. In the present study we found that the outer and middle layer of the notochordal sheath were both expressing fish collagen type I. Previous studies did not detect any type of collagen directly in tissue section of amphioxus notochordal sheath using immunohistochemical methods. The types of collagen were analysed in the notochordal sheath of amphibian larvae and chicken embryo [9]. Thus, in chick embryo, the notochord was surrounded by collagen identified as type X1(II) and by sulphated glycosaminoglycans [9]. In human embryos, the notochord is transformed from an apparently undifferentiated organ into an organ with secretory activity, producing microfibrils and depositing acid mucopolysaccharides in the notochordal sheath [30].

In the present study, the inner layer of the amphioxus notochordal sheath was of fine granular structure and was not positive to fish collage type I. This could be explained by the fact that the basal lamina in vertebrates contains collagen type IV which is amorphous in structure [31,32]. The applied alpha smooth-muscle actin antibody was expressed in the area where the sheath was attached to the notochordal cells, as well as in the cytoplasm of some notochordal cells. The actin antibody was derived from human tissues and its expression in the amphioxus tissues confirmed the high preservation of this protein during evolution.

Actins comprise a relatively small family of structural proteins found in all eukaryotes [33]. Cytoplasmic actin is a major component of the cytoskeleton and, thus, has a wide distribution in all types of tissues in organisms from protozoa to mammals [33]. Previous studies confirmed presence of 12 different muscle genes in the amphioxus notochord [10]. To investigate the evolution of developmental mechanisms in chordates, cDNA clones for two amphioxus actin genes, BfCA1 and $B F M A 1$, were isolated [33]. BfCA1 encoded a cytoplasmic actin and was expressed in the amphioxus notochord during larval stage while BfMA1 was a vertebrate-type muscle actin gene and was not detectable in the amphioxus notochord [33]. Considering the antibodies applied to other cytoskeletal components, such as intermediate filaments and microtubules, we found that the notochordal sheath was more or less strongly reactive 
to all cytokeratins, desmin and vimentin in the area of notochordal sheath close to epipharyngeal groove. Cytokeratins are intermediate filaments usually found in epithelial tissue $[20,32,34]$. The notochordal tissue is also ontogenetically derived from the epithelium of the archenteron [35]. Investigations on molecular level disclosed that genes that determine the type I and II keratins are expressed in the amphioxus tissues [36]. However, data about their immunohistochemical expression in notochord of amphioxus were missing. In immunohistochemical studies on human fetal notochord all of the notochord specimens were positive for CK 8 and CK 19, but none showed a positive immunoreaction for CK 7, or CK 18 [37]. In the present study, the expression of the cytokeratin protein antibodies in the connective tissue structures, such as notochordal sheath could be explained by coexpression of cytokeratins and vimentin in certain cells as previously shown in the notochord of human and mouse embryos [34, 38, 39]. Vimentin is type III intermediate filament found in the mammalian mesenchymal cells and also in other vertebrates, from fish to birds [32, 34, 40]. The expression of desmin antibody (also type III intermediate filament) in the outer layer of the notochordal sheath is similar to those of vimentin. This could be explain by polymerization of vimentin and desmin [31]. Btubulin is a main component of the microtubules [32]. The applied antibody to B-tubulin also showed positivity in the notochordal sheath in the area of the epipharyngeal groove. Precise explanation of reactivity in that specific region to microfilament and microtubular proteins remains to be solved on electron-microscopic level. Obviously, this part of notochordal sheath has a very peculiar structure and composition.

According to the results of our study, we can conclude that the notochordal sheath is connective tissue layer containing collagen type I as a major extracellular matrix protein. The sheath showed also a strong immunoreactivity to most of the applied antibodies to intermediate filaments and microtubules, but exclusively in the area of the epipharyngeal groove. Expression of human smooth muscle actin in some amphioxus notochordal cells and places of their attachment to the notochordal sheath confirms not only the muscular nature of the notochord, but also a high conservation of genes encoding actin protein during evolution.

\section{Acknowledgments}

We thank Mrs Asja Miletić for her skilful technical assistance.

\section{Conflict of interest}

The authors have declared that no conflict of interest exists

\section{References}

1. Müller W. Beobachtungen des patologischen Instituts zu Jena. I Ueber den Bau der Chorda dorsalis. Z Naturw. 1871; 6: 327353.
2. Schneider KC. Lehrbuch der vergleichenden Histologie der Tiere. Jena: Verlag von Gustav Fischer, 1902.

3. Schneider A. Beitraege zur vergleichenden Anatomie und Entwicklungsgeschichte der Wirbelthiere. Berlin: G Reimer, 1875.

4. Ognev SI, Fink N. Zoologija kralješnjaka. Zagreb: Školska knjiga, 1953.

5. Flood PR. Fine structure of the notochord of amphioxus. Symposia of the Zoological Society of London 1975; 36: 81-104.

6. Eakin RM, Westfall JA. Fine structure of the notochord of the amphioxus. J Cell Biol 1962; 12: 646-651.

7. Harrison FW, Ruppert EE. Microscopic Anatomy of Invertebrates. New York: Wiley-Liss, 1997.

8. Bočina I, Saraga-Babić M. The notochordal sheath in amphioxus - an ultrastructural and histochemical study. Collegium Antropologicum; in press.

9. Malacinski GM, Woo Youn B. The structure of the anuran amphibian notochord and re-evaluation of its presumed role in early embryogenesis. Differ 1982; 21:13-21.

10. Suzuki MM, Satoh N. Genes expressed in the amphioxus notochord revealed by EST analysis. Dev Biol 2000; 224: 168177.

11. Urano A, Suzuki MM, Zhang P, et al. Expression of musclerelated genes and two MyoD genes during amphioxus notochord development. Evol and Dev 2003; 5:447-458.

12. Karabinos A, Riemer D, Erber A, et al. Homologues of vertebrate type I, II and III intermediate filament (IF) proteins in an invertebrate: the IF multigene family of the cephalochordate Branchiostoma. FEBS Letters 1998; 437: 15-18.

13. Luke GN, Holland PWH. Amphioxus type I keratin cDNA and the evolution of intermediate filament genes. J Exp Zool 1999; 285:50-56.

14. Karabinos A, Wang J, Wenzel D, et al. Developmentally controlled expression patterns of intermediate filament proteins in the cephalochordate Branchiostoma. Mechanisms of Development 2001; 101: 283-288.

15. Sheehan DC, Hrapchak BB. Theory and practice of histotechnology. Ohio: Battelle Press, 1980.

16. Debus E, Weber K, Osborn M. Monoclonal antibodies specific for glial fibrillary acidic (GFA) protein and for each of the neurofilament triplet polypeptides. Differ 1983; 25: 193-203.

17. Gown AM, Vogel AM. Monoclonal antibodies to human intermediate filament proteins:III. Analysis of tumors. Amer J Clin Pathol 1985; 84: 413-424.

18. Skalli O, Ropraz P, Trzeciak A, et al. A monoclonal antibody against a-smooth muscle actin: A new probe for smooth muscle differentiation. J Cell Biol 1986; 103: 2787-2796.

19. Van Muijen GNP, Ruiter DJ, Warnaar SO. Coexpression of intermediate filament polypeptides in human fetal and adult tissues. Lab Invest 1987; 57: 359-369.

20. Goddard MJ, Wilson B, Grant JW. Comparison of commercially available cytokeratin antibodies in normal and neoplastic adult epithelial and non-epithelial tissues. J Clin Pathol 1991; 44: 660-663.

21. Weintraub $H$, Davis $R$, Tapscott $S$, et al. The myoD gene family: nodal point during specification of the muscle cell lineage. Science 1991; 251: 761-766.

22. Wang PN, Zee S, Zarbo RJ, et al. Coordinate expression of cytokeratins 7 and 20 defines unique subsets of carcinomas. Appl Immunohistochem 1995; 22: 99-107.

23. Kobayashi N, Mundel P. A role of microtubules during the formation of cell processes in neuronal and non-neuronal cells. Cell and Tiss Res 1998; 291: 163-174.

24. Hermanns S, Müller HW. Preservation and detection of lesioninduced collagenous scar in the CNS depend on the method of tissue processing. Brain Research Protocols 2001; 7: 162-167. 
25. Moreno N, López JM, Sánchez-Camacho C, et al. Embryonic and larval development of NADPH-diaphorase/ nitric oxide synthase reactivity in the brain of amphibian Pleurodeles waltl. Int J Dev Biol 2001; 45: 81-82.

26. Duncan JE, Warrior R. The cytoplasmic dynein and kinesin motors have interdepedent roles in pattering the Drosophila oocyte. Current Biology 2002; 12: 1982-1991.

27. Lechner A, Leech CA, Abraham EJ, et al. Nestin-positive progenitor cells derived from adult human pancreatic islets of Langerhans contain side population (SP) cells defined by expression of the ABCG2 (BCRP1) ATP-binding cassette transporter. Biochem and Biophys Res Commun 2002; 293: 670-674.

28. Castro A, Becerra M, Manso MJ, et al. Anatomy of the Hesse photoreceptor cell axonal system in the central nervous system of amphioxus. J Comp Neurol 2006; 494: 54-62.

29. Ruppert E, Barnes D. Invertebrate Zoology. New York: Saunders College Publishing, 1994.

30. Shinohara H, Tanaka O. Development of the notochord in human embryos: Ultrastructural, histochemical, and immunohistochemical studies. Anat Rec 1988; 220: 171-178.

31. Junqueira LC, Carneiro J, Kelley RO. Osnove histologije. Zagreb: Školska knjiga, 1999.

32. Kierszenbaum AL. Histology and cell biology. An introduction to pathology. St. Louis: Mosby Inc, 2002.

33. Kusakabe R, Kusakabe $\mathrm{T}$, satoh $\mathrm{N}$, et al. Differential gene expression and intracellular mRNA localization of amphioxus actin isoforms throughout development: Implications for conserved mechanisms of chordate development. Dev Genes Evol 1997; 207: 203-215.

34. Götz W, Kasper M, Fischer G, Herken R. Intermediate filament typing of the human embryonic and fetal notochord. Cell and Tiss Res 1995; 280: 455 - 462.

35. Stach, T. The ontogeny of the notochord of Branchiostoma lanceolatum. Acta Zool 1999; 80: 25-33.

36. Luke GN, Holland PWH. Amphioxus type I keratin cDNA and the evolution of intermediate filament. J Exp Zool 1999; 285:5056.

37. Naka T, Iwamoto $\mathrm{Y}$, Shinohara N, et al. Cytokeratin subtyping in chordomas and the fetal notochord: an immunohistochemical analysis of aberrant expression. Mod Pathol 1997; 10: 545-551.

38. Souza PC, Katz SG. Coexpression of cytokeratin and vimentin in mice trophoblastic giant cells. Tiss and Cell 2001; 33: 40-45.

39. Lehtonen E, Stefanović V, Saraga-Babić M. Changes in expression of intermediate filaments and desmoplakins during development of human notochord. Differ 1995; 59: 43-49.

40. Mücke N, Wedig T, Bürer A, et al. Molecular and biophisical characterization of assembly-starter units of human vimentin. J Mol Biol 2004; 340: 97-114. 